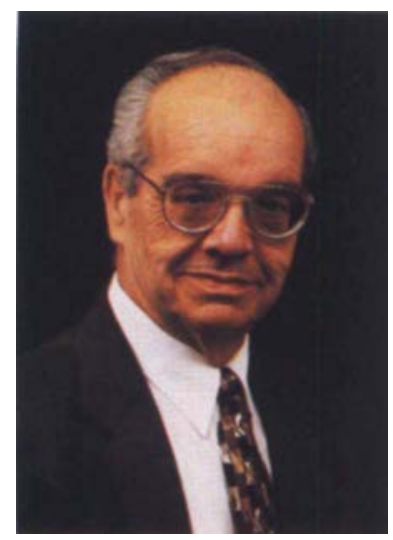

\title{
Grass-roots effort sets priorities; Division creates new budget process to meet them
}

\author{
W.R. GOMES \\ Vice President \\ Agriculture and Natural Resources
}

$\mathrm{T}$ he last 4 years have marked the most comprehensive grass-roots planning effort ever undertaken by UC's Division of Agriculture and Natural Resources, one involving hundreds of Division members, external clientele and cooperating government agency professionals.

As a part of this continuing process, we recently published a working strategic plan, The Challenge of Change (see page 5). The document itself is one of several "living" plans that will be revised indefinitely. It reflects current thinking on our mission, program priorities and organizational strategies that serve as benchmarks for continuing discussion.

Strategic planning has also produced a new budgetary process, one designed to help us respond flexibly to those priorities and to meet the emerging needs of Californians.

This effort is nothing less than essential if we are to fulfill our historic charter in today's radically changed environment. In the words of President Lincoln, the land-grant univerisities were "built on behalf of the people." They were charged by the Morrill Act of 1862 to develop "useful and practical information ... and to promote scientific investigations and experiments." In 1914, the Smith-Lever Act launched Cooperative Extension to help disseminate that information.

This legislation was originally intended to transform a struggling, subsistence-level agriculture into a production system that would serve the economic and food and fiber needs of a nation. Today, the charge has taken on a larger meaning. As the nation's largest land-grant university, with a highly diverse and geographically diffuse clientele, we face daunting challenges. Among those cited in The Challenge of Change:

- The urbanization of California - and with it, the significant reduction in the legislative power once enjoyed by agriculture.

- Accelerating population growth: The state's population is expected to double to 63 million by 2040.

- Greater cultural diversity and socio-economic stratification of Californians.

- Increasing competition for land and other natural resources.

- Increasing threats to environmental quality and rising public concern about environmental health and food safety.

- Increasing global competition for California industry.

- Continuing governmental regulation of agriculture, the landscape and natural resource development.

We must also continue to adapt to intense financial pressure from declining federal, state and county funding. In the last 10 years, the Division's total expenditures have decreased by $8 \%$ in real dollars. The 1990 s brought 5 years of budget cuts; the resulting early retirement programs led to a permanent reduction of $17 \%$ of our faculty on the Davis, Riverside and Berkeley campuses and in county offices statewide.

Our mission, as stated in the strategic plan, is to serve California through the creation, development and application of knowledge in agricultural, natural and human resources. Given the breadth of this mission, we must channel limited resources to areas of critical need where we can have the greatest impact.

The Division's new budget-reallocation process is designed to help us do so, while moving decision-making authority closer to those doing the work. Beginning July 1,3.3\% of every unit's permanent $C E$ budget went into a reallocation pool. In this way, $10 \%$ of the $\mathrm{CE}$ budget could be redirected to highest priority efforts over the next 3 years. The funds in the pool are awarded to deans and regional directors as annual block grants.

In past years, units had less control over their budgets, largely because open $\mathrm{CE}$ academic positions and their funding reverted to the Office of the Vice President. Decisions on filling, or not filling, positions were ultimately made at that level, on an ad hoc basis. Planning at the campus and regional level was difficult.

The reallocation process will enable us to encourage teamwork in addressing high-priority needs. While we will maintain essential activities and build upon areas of existing preeminence, this will allow us to take advantage of emerging opportunities and to adjust more rapidly to change.

The publication of The Challenge of Change marks an interim step, not an end, in the planning process. Each year we will take a fresh look at the issues affecting the state and the university, then adjust our priorities, particularly in light of feedback from our external stakeholders. For instance, in June, after publishing the updated strategic plan, we consulted with 270 clientele, about half of whom participated in focus groups at four locations across the state. What they told us will be an integral component of the next cycle in the planning process.

Their four recurring messages were that the Division needs to focus more on clientele, to collaborate and coordinate more with those outside the Division, to strengthen the extension function and to be more accountable. These suggestions are already in the hands of the Program Planning Advisory Committees as they develop their recommendations for this year.

Societal and economic developments in California and the world have challenged us to revisit and rethink our systems. Through a continuing dialogue with our partners both inside and outside the University, we can adapt to the challenges, and continue to provide Californians with the research-based information they need to improve their quality of life and enhance the environment for all. 